\title{
Fenômeno de Raynaud
}

\author{
Raynaud's phenomenon
}

Cristiane Kayser ${ }^{(1)}$, Marcelo José Uchôa Corrêa ${ }^{(2)}$, Luís Eduardo Coelho Andrade ${ }^{(3)}$

\section{RESUMO}

O fenômeno de Raynaud (FRy) caracteriza-se por episódios reversíveis de vasoespasmos de extremidades, associados a palidez, seguido por cianose e rubor de mãos e pés, que ocorrem usualmente após estresse ou exposição ao frio. O FRy primário é um evento funcional benigno e não está associado a nenhuma doença ou condição subjacente. Já o FRy secundário pode estar associado a uma série de condições, principalmente a doenças reumáticas autoimunes. Na esclerose sistêmica (ES), o FRy é a manifestação inicial mais frequente. No FRy secundário às doenças do espectro da ES, complicações como lesões isquêmicas de extremidades são frequentes. Nos últimos anos, avanços no estudo da fisiopatologia do FRy e da doença vascular na ES propiciaram o surgimento de opções terapêuticas bastante promissoras para essa manifestação. Nesta revisão pretendemos discorrer principalmente sobre a patogênese, a investigação clínica e o tratamento do FRy, com ênfase nos novos tratamentos disponíveis.

Palavras-chave: Esclerose sistêmica, fenômeno de Raynaud, tratamento, revisão.

\section{INTRODUÇÃO}

O fenômeno de Raynaud (FRy), como descrito em 1862 por Maurice Raynaud, caracteriza-se por episódios reversíveis de vasoespasmos de extremidades, associados a alterações de coloração típicas que ocorrem após exposição ao frio ou em situações de estresse. ${ }^{1,2}$ Geralmente ocorre em mãos e pés e em casos mais graves pode também acometer o nariz, orelhas ou língua. As alterações de coloração são classicamente descritas em três fases sucessivas: palidez (fase isquêmica), cianose

\begin{abstract}
Raynaud's phenomenon (RP) is an episodic vasospasm of the peripheral arterioles, causing pallor followed by cyanosis and redness of the fingers and toes, usually in response to stress or cold exposure. Primary Raynaud's phenomenon is a benign event and occurs without an underlying disease. In contrast, secondary Raynaud's phenomenon can occur in association with several underlying diseases or conditions, mostly autoimmune rheumatic diseases. In systemic sclerosis (SSc), RP is the most frequent initial manifestation. In RP secondary to $S S$-related diseases, digital ischemic lesions are a frequent problem. In recent years, advances in the understanding of the physiopathology of RP have favored the development of novel promising therapeutic alternatives for this clinical condition. This article presents a review of the pathogenesis, clinical investigation and treatment of $R P$, with special emphasis in novel therapeutic modalities.
\end{abstract}

Keywords: Systemic sclerosis, Raynaud's phenomenon, treatment, review

(causada por venoestase e desoxigenação) e rubor (hiperemia reativa/reperfusão), ${ }^{2,3}$ Dor e/ou parestesias podem também estar associadas aos ataques, causando desconforto ao indivíduo.

O FRy é uma desordem relativamente comum e, na grande maioria dos casos, caracteriza-se por ser um evento funcional benigno, não havendo qualquer doença subjacente, sendo assim chamado de FRy primário ou idiopático. ${ }^{2} \mathrm{O}$ FRy pode, no entanto, ser secundário a uma série de condições locais ou sistêmicas, destacando-se as doenças reumáticas autoimunes, o que torna esse tema de especial interesse para o reumatolo-

\footnotetext{
Recebido em (Received on) 17/11/2008. Aprovado (Approved), após revisão, em 05/01/09. Declaramos a inexistência de conflitos de interesse (We declare no conflict of interest).

Disciplina de Reumatologia, Escola Paulista de Medicina, Universidade Federal de São Paulo (UNIFESP)

Division of Rheumatology, Escola Paulista de Medicina, Universidade Federal de São Paulo (UNIFESP)

1. Médica Assistente e responsável pelo Ambulatório de Esclerose Sistêmica da Disciplina de Reumatologia da UNIFESP. Médica do Setor de Capilaroscopia Periungueal - Fleury Medicina Diagnóstica.

1. Physician, in charge of the Systemic Sclerosis Clinic of the Division of Rheumatology of UNIFESP. Doctor of the Periungueal Capillaroscopy Sector - Fleury Medicina Diagnóstica.

2. Pós-graduando da Disciplina de Reumatologia da UNIFESP.

2. Postgraduate of the Division of Rheumatology of UNIFESP.

3. Professor Adjunto - Livre Docente, Disciplina de Reumatologia da UNIFESP.

3. Associate Professor, Division of Rheumatology of UNIFESP.

Endereço para correspondência (Correspondence to):Cristiane Kayser, Rua Botucatu, 740 - $3^{\circ}$ andar, São Paulo, SP, CEP (Zip Code): 04023-062. E-mail: criskayser@terra.com.br
} 
medicamentosa com vasodilatadores, o princípio básico para o tratamento de úlceras de extremidades em pacientes com FRy inicia-se com debridamento e limpeza adequada das lesões, seguido do uso de curativos oclusivos e antibioticoterapia quando necessário. Curativos oclusivos podem ser úteis tanto para a proteção de áreas suscetíveis a traumas assim como para a cicatrização de úlceras. ${ }^{57}$ Curativos tópicos de hidrocoloide se mostraram seguros e eficazes em promover a cicatrização de úlceras digitais em um ensaio controlado e randomizado. ${ }^{58}$ Pacientes com isquemia sustentada podem requerer hospitalização para tratamento mais agressivo. Anticoagulação com heparina por 24-72 horas pode ser considerada para casos de eventos isquêmicos agudos com rápida evolução. ${ }^{37}$

\section{TRATAMENTO CIRÚRGICO}

Simpatectomia deve ser reservada para pacientes com FRy grave com complicações associadas que não responderam ao tratamento medicamentoso. $\mathrm{O}$ efeito costuma ser temporário, principalmente em pacientes com FRy secundário à ES. Simpatectomia digital ou simpatectomia química com lidocaína ou bupivacaína pode ser utilizada em pacientes com isquemia crítica e úlceras ativas que não responderam ao tratamento farmacêutico. Simpatectomia cervical é relacionada a complicações pós-operatórias, como síndrome do martelo hipotenar e neuralgia e é raramente recomendada. ${ }^{38}$

\section{CONCLUSÕES}

O fenômeno de Raynaud é relativamente frequente na população geral, sendo importante a diferenciação entre FRy primário e secundário. $\mathrm{O}$ tratamento do FRy tem sofrido avanços com o advento de novas drogas com potente ação vasodilatadora. No entanto, proteção ao frio e uso de bloqueadores do canal de cálcio são ainda os tratamentos de primeira escolha. Associação terapêutica e novas drogas vasodilatadoras devem ser utilizadas em pacientes que não responderam às medidas iniciais e às drogas bloqueadoras de canal de cálcio. Novas alternativas, como os antagonistas dos receptores de endotelina 1 , os inibidores da fosfodiesterase $\mathrm{V}$ e os análogos da prostaciclina parecem ter lugar no manejo de úlceras isquêmicas de difícil tratamento, principalmente em pacientes com ES.

\section{Raynaud's phenomenon}

\section{INTRODUCTION}

Raynaud's phenomenon (RP), as described in 1862 by Maurice Raynaud, is characterized by reversible episodes of vasospasm of extremities, associated with changes in color that typically occur after exposure to cold or in stress situations. ${ }^{1,2}$ It generally occurs in the hands and feet and in more severe cases, can also attack the nose, ears or tongue. The changes in color are classically described in three successive phases: paleness (ischemic phase), cyanosis (caused by venostasis and deoxygenation) and redness (reactive hyperemia/reperfusion). ${ }^{2,3}$ Pain and/or paresthesias that cause discomfort to the individual can also be associated with the attacks.

$\mathrm{RP}$ is a relatively common disorder and, in most cases, is a benign functional event, without any underlying disease, being called primary or idiopathic RP. ${ }^{2}$ However, RP can be secondary to several local or systemic conditions, mostly autoimmune rheumatic diseases, which make this a theme of special interest to the rheumatologist. Especially in RP secondary to systemic sclerosis (SSc), the vasospastic events are usually more intense and frequent, and often associated with ischemic ulcers and progressive resorption of the extremities.

Recently, new insights into the pathogenesis of RP and the vascular disease in the SSc have led to the development of new therapeutic options for this manifestation. In this review, we intend to discourse mainly about the pathogenesis, the diagnosis investigation and the treatment of RP, with emphasis on novel treatments available.

\section{EPIDEMIOLOGY}

$\mathrm{RP}$ is relatively frequent, occurring around 3,5 to $15 \%$ of the general population. ${ }^{4-6}$ Differences found in the prevalence of RP result from the criteria used for the diagnosis, geographic and climatic variations, as well as population distinctive features. It is more common in women, young individuals, and among members of the same family. In a study conducted in the United States with Caucasian patients, the prevalence of RP was $11 \%$ in women and $8 \%$ in men, ${ }^{7}$ while in another study with adolescents the prevalence was $15 \%$ in the female sex. ${ }^{8}$ The average age for the onset of primary RP is 14 years of age, and only $27 \%$ begin around 40 years of age or later. ${ }^{9}$ In contrast, the secondary RP tends to begin in adult life. The frequency and severity of the episodes are influenced by daily variations in temperature with sharp exacerbation during winter. ${ }^{7}$ 


\section{PATHOGENESIS}

Although the pathogenesis of RP is not yet completely understood, several mechanisms involved in the vasospastic events are recognized (Figure 1). The vascular tonus is controlled by a complex interaction between endothelial cells, smooth musculature of the vascular wall, soluble mediators and neuronal stimulation. An unbalance between vasoconstriction and vasodilatation, in favor of vasoconstriction, is a central event in the physiopathology of RP. ${ }^{10}$ It should be remembered that the alterations found vary according to the presence or not of an associated disorder. While primary RP is related to functional alterations alone, in RP secondary to SSc, structural alterations of the vascular wall are also found. ${ }^{3}$

The $\alpha_{2}$-adrenergic receptors are the main mediators of the vasoconstriction induced by cold in the smooth musculature cells. ${ }^{11}$ Hyperactivity of the $\alpha_{2}$-adrenoceptor and alteration in the production of neuropeptides (e.g. calcitonin gene-related peptide), are some of the mechanisms involved in the vasospasm episodes induced by cold in primary and secondary RP. ${ }^{12}$ Moreover, the endothelium plays an active role in regulating vascular tone. The endothelial cells produce a number of

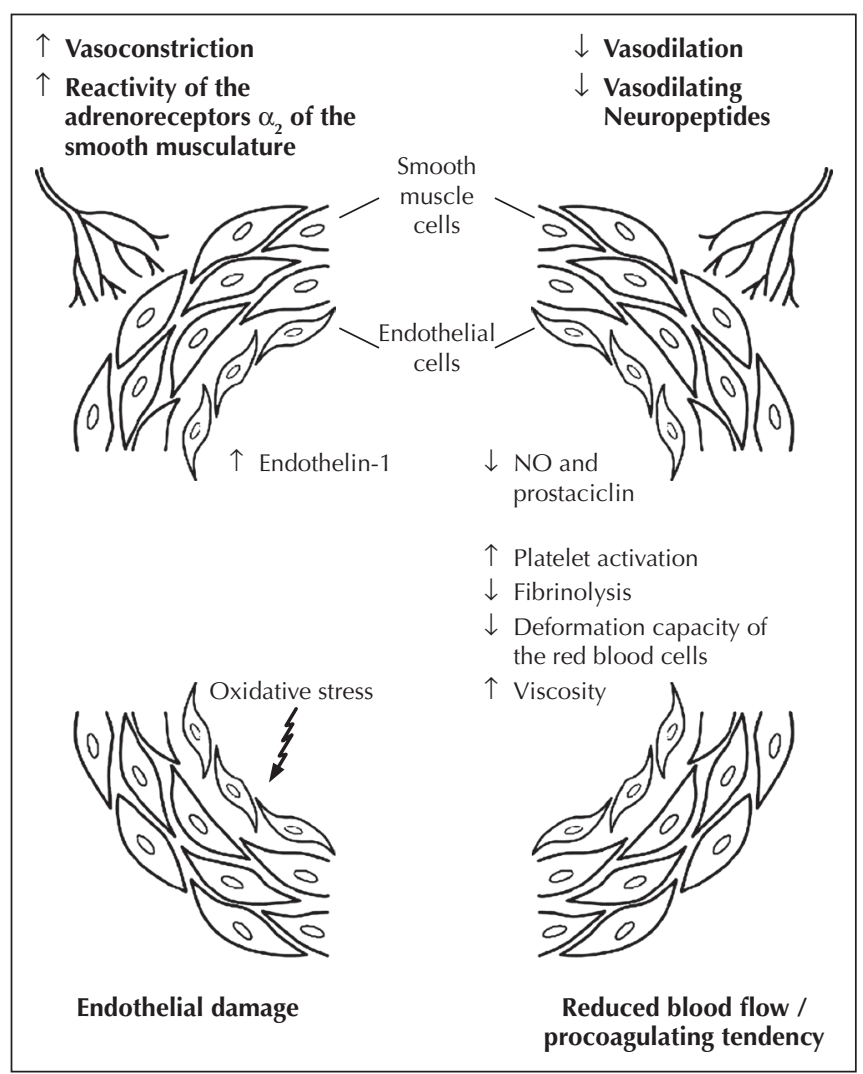

Figure 1. Pathogenic mechanisms of Raynaud's phenonomenon. Adapted from Herrick, 2005. ${ }^{10}$ vasodilatory mediators, including endothelin, nitric oxide (NO), prostacyclin, and also vascular adhesion molecules. Releasing these mediators is a delicately regulated process in healthy individuals. ${ }^{13}$ In RP, especially when secondary to SSc, endothelial lesion and activation cause an imbalance between the production of vasoconstrictors and vasodilatory mediators, with an increase in the production of endothelin-1 (powerful vasoconstrictor) and a decrease in the production of $\mathrm{NO}$ and prostacyclin (vasodilating agents). ${ }^{10}$ The vasodilating effect of the NO and the prostacyclins occur through the cyclic AMP and cyclic GMP, being its degradation controlled by many phosphodiesterases. ${ }^{14}$ This fact has been explored from the therapeutics point of view with the using of phosphodiasterase $\mathrm{V}$ (e.g. sildenafil) and prostacyclin analogs. On the other hand, the production blockage of vasoconstricting substances has been also explored, with the use of endothelin-1 receptors antagonists (e.g. bosentana).

Besides the functional and contractile alterations, structural alterations are found in secondary RP, mainly in SSc. Proliferation and intimal fibrosis of the small arteries and arterioles result in decrease of vessel lumen; these alterations cause decrease of blood flow and lead to a state of chronic ischemia of the involved organs. ${ }^{15,16}$ In the microcirculation, capillary loss and dilatation are the most remarkable feature and lead to an important distortion of the capillary vascular architecture. The alterations in the microcirculation are also frequently associated with intravascular thrombus, which can cause a complete obstruction of the vessel lumen. This state of tissue hypoperfusion should favor the neoangiogenesis, however, the formation of new capillaries is rarely observed, being usually observed large avascular areas, suggesting defects in the angiogenesis or in the vascular repair. ${ }^{12}$ This observation is possibly related to the reduction of VEGF (vascular endothelial growth factor), which would be important to the repopulation of capillary in the affected tissues. In fact, in a recent study of gene expression with cDNA microarray platform, our group demonstrated a significative decrease in the expression of VEGF gene by dermal fibroblasts of patients with SSc compared to cells of healthy controls. ${ }^{17}$

In this context, the vasospasm of RP secondary to SSc is usually more serious, leading to reperfusion-ischemia episodes. It is suggested that in SSc, it's suggested that the repeated episodes of reperfusion-ischemia cause an increase in free radicals activity (oxidative stress) and a persistent activation of the endothelial system. ${ }^{10}$ These factors could predispose to new vasospastic episodes, and so creating a vicious circle in which exists vasospasm, generation of free radicals, endothelial lesion and more vasospasm. ${ }^{16,18}$ 
Finally, several intravascular abnormalities, such as platelet activation, increase of the fibrinolysis, leukocyte activation, and reduction of the deformation capacity of the red blood cells have been implicated as coadjuvant factors in the RP pathogenesis. ${ }^{10,18-21}$

\section{CLINICAL INVESTIGATION OF RAYNAUD'S PHENOMENON}

In clinical practice, it's of extreme importance to differentiate patients with primary and secondary RP and predict which patients with RP will evolve to some other disease, mainly the rheumatic autoimmune diseases. This differentiation is extremely important to define the severity, prognostic factors and the most adequate treatment. In this context, all patients should be submitted to a thorough clinical history and physical exam. On top of that, we recommend performing a periungueal capillaroscopy, search for antinuclear antibodies (ANA) and inflammatory markers in all cases. ${ }^{2}$

The primary RP occurs generally in young women and about $25 \%$ of the patients have a family history of RP in first degree relatives. ${ }^{22}$ In primary RP the attacks are usually symmetric and less severe. Necrosis, ulceration, gangrene or reabsorption of of the affected extremities are not observed. The erythrocyte sedimentation rate (ESR) is usually normal. The periungueal capillaroscopy (PUC) is also usually normal, but eventually can be observed some ectasiated capillary. The ANA is usually negative (Table 1). ${ }^{2}$ However, it should be remembered that about $10 \%$ of the population have a positive ANA. In this context, the titer and morphologic pattern of the ANA are important criteria to be evaluated. In general, the ANA found in healthy people and in patients with primary RP shows low titers (up to 1:160). The main patterns of fluorescence are the nuclear fine speckled and the dense fine speckled. The latter deserves a special attention, as it usually is not associated with autoimmune systemic diseases, even when in high titers.

\section{Table 1}

Diagnostic criteria for primary Raynaud's phenomenon

\begin{tabular}{l}
\hline Episodic attacks of pallor or cyanosis of extremities \\
Strong and symetric peripheric pulses \\
Absence of microscars, ulcers or digital gangrene \\
Normal periungueal capillaroscopy \\
Normal erythrocyte hemosedimentation rate $(<20 \mathrm{~mm} /$ hour) \\
Absence of antinuclear antibodies (ANA titers $<1: 100)$
\end{tabular}

Adapted from LeRoy and Medsger, 1992.
As highlighted before, RP is considered to be secondary when it is associated with some underlying condition or disease; and among the causes of secondary RP, the autoimmune rheumatic diseases are emphasized (Table 2) ${ }^{23} \mathrm{RP}$ is present in more than $90 \%$ of the patients with SSc, in approximately $85 \%$ of the patients with mixed connective tissue disease, in 10 to $45 \%$ of the patients with systemic lupus erythematosus, in 33\% of those with Sjögren's syndrome, in $20 \%$ of the cases of dermatomyositis or poliomyositis, and also in $10 \%$ of the cases of rheumatoid arthritis. ${ }^{24}$

It is also known that approximately $10 \%$ of the patients with an initial diagnosis of primary RP developed subsequently a rheumatic autoimmune disease, being of fundamental importance the identification of the patients with significative risk for the developing of such conditions (Table 3) ${ }^{25}$ Especially in diseases of the SSc spectrum, RP can be an initial isolated manifestation, preceding for years or even decades the other manifestations of the disease. A secondary cause for RP should be suspected in the presence of very intense episodes of RP, if the beginning of the symptoms happens after the 30 years of age and in the presence of trophic alterations on the extremities, such as cutaneous thickening, digital pulp atrophy, microscars

Table 2

Causes for secondary Raynaud's phenomenon

\begin{tabular}{|c|c|}
\hline Rheumatic diseases & $\begin{array}{l}\text { Systemic sclerosis } \\
\text { Mixed Connective Tissue Disease } \\
\text { Systemic Lupus Erythematosus } \\
\text { Sjögren syndrome } \\
\text { Dermatomyosites } \\
\text { Rheumatoid arthritis } \\
\text { Vasculitis }\end{array}$ \\
\hline Drugs and toxic agents & $\begin{array}{l}\text { Beta blockers (including in ocular solution) } \\
\text { Ergot derivated susbtances } \\
\text { Cancer chemotherapy } \\
\text { Ciclosporin } \\
\text { Interferon } \alpha \text { and } \beta \\
\text { Cocaine } \\
\text { Tobbacco adiction (probable) }\end{array}$ \\
\hline Endocrine diseases & $\begin{array}{l}\text { Hypothyiroidism } \\
\text { Pheochromocytoma } \\
\text { Carcinoid syndrome }\end{array}$ \\
\hline $\begin{array}{l}\text { Trauma or lesion of } \\
\text { the great vessels } \\
\text { (unillateral Raynaud) }\end{array}$ & $\begin{array}{l}\text { Lesion by use of vibratory instruments } \\
\text { Ulnar aneurism (Hypothenar } \\
\text { hammer syndrome) } \\
\text { Thoracic outlet syndrome }\end{array}$ \\
\hline Arterial disease & $\begin{array}{l}\text { Thromboangiites obliterans } \\
\text { Atheroma } \\
\text { Peripheral embolism }\end{array}$ \\
\hline $\begin{array}{l}\text { Hemathologic disorders } \\
\text { Neoplasias }\end{array}$ & $\begin{array}{l}\text { Crioglobulinemia } \\
\text { Policitemy } \\
\text { Mielo and lymphoproliferative diseases } \\
\text { Ovary carcinoma }\end{array}$ \\
\hline
\end{tabular}

MCTD = Mixed Connective Tissue Disease; SLE = Systemic Lupus Erythematosus 
or digital ulcers. ${ }^{26}$ On top of that, a series of prospective studies with individuals with RP also demonstrates that abnormal findings at the periungueal capillaroscopy and/or the presence of some autoantibodies in high titers identify a group of patients with a high risk of developing systemic sclerosis and correlated diseases..$^{27-31}$ In individuals with an isolated RP, the pattern SD to PUC presents a positive predictive value for the developing of an autoimmune rheumatic disease around $50 \%$ and a negative predictive value of more than $90 \%$.

The PUC is a noninvasive test, considered an important method for identification of morphologic alterations in the microcirculation in diseases associated with the SSc spectrum. ${ }^{32}$ In primary RP, the PUC presents a pattern similar to normal, that is, presence of capillaries loops of homogeneous size, shape and color transversally disposed along the cuticle (Figure 2A). ${ }^{33}$ Some dilated capillaries can be found. While in RP associated with diseases of the SSc spectrum, the PUC presents a microangiopathic scenario denominated SD pattern, which is characterized by the presence of capillary dilation and distortion associated with areas of devascularization (Figure 2B). ${ }^{34}$ The presence of micropetechiae of disseminated distribution is also associated with SD pattern. SD pattern is described mainly in the SSc, dermatomyositis, mixed connective tissue disease and overlapping SSc syndromes. It is also described in $5-10 \%$ of the patients with systemic lupus erythematosus, representing a subgroup of patients characterized by presenting sausage fingers, esophageal dismotility, RP and antibodies anti-U1-RNP. ${ }^{35}$

Table 3

Main differences between primary and secondary Raynaud`s phenomenon

\begin{tabular}{lcc}
\hline & Primary & Secondary \\
\hline Prevalence & Common & Rare \\
Association with AIRD & No & Yes \\
Associated to ANA & No & Generally \\
Microangiopathy in PUC & No & Generally \\
RP family history & Yes & No (occasionaly) \\
Pharmacological treatment & No (occasionaly) & Frequentely \\
\hline Complications & No (rarely) & Yes \\
\hline
\end{tabular}

AIRD = Autoimmune rheumatic disease; ANA = Antinuclear antibody. PUC = Periungueal capillaroscopy.

Adapted from Block and Winston Sequeira, 2001.
The presence of ANA has a positive predictive value relatively low for the development of an autoimmune rheumatic disease (30\%); ${ }^{25}$ notwithstanding, the presence of an antibody against some specific autoantigens is much more suggestive of a secondary cause. ${ }^{31}$ When analyzing the ANA test, facing a positive result, a fundamental point for the correct appreciation of the test is the evaluation of titer and fluorescence pattern. Fluorescence pattern might suggest some specificity of autoantibodies, guiding the doctor on the suspect diagnosis or on the next steps of the laboratorial investigation. However, it is pointed out that to most autoantibodies, the information from fluorescence pattern is just a preliminary guide, the specificity of the antibody should be confirmed by other immunological methods, since the finding of some autoantibodies have a diagnostic and prognostic stronger value. Among these, stand

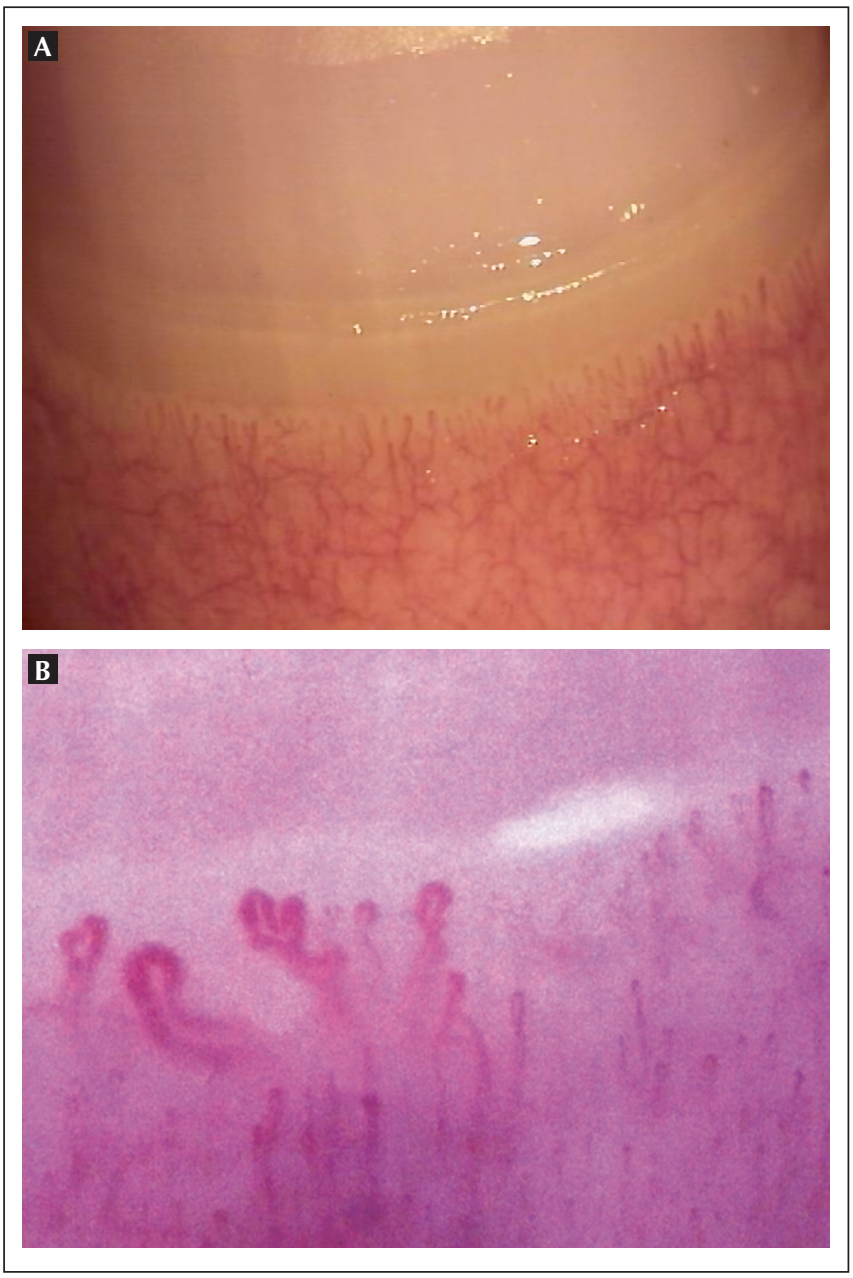

Figure 2. Periungueal capillaroscopy with normal capillaroscopic pattern (capillaries with homogeneous shape, size and distribution) (A), and with microangiopathy SD pattern (dilated capillaries in devascularization areas) (B). 
out in the context of SSc, the antibodies anticentromere, antiDNA topoisomerase I (Scl-70), anti-RNA polymerases I and III, and antifibrilarin. In the context of the systemic lupus erythematosus, the antibodies native anti-DNA, antinucleosome, anti-Sm, antiprotein P ribosomal and anti-PCNA are relevant due to high specificity. The antibody anti-U1-RNP strongly favors an autoimmune rheumatic disease, including mixed connective tissue disease, systemic lupus erythematosus and SSc itself. Although the antibody anti-PM-Scl is frequently found in the overlapping syndrome, it can also be eventually found in patients with an isolated SSc.

According to the indication of the initial clinical test, the performance of more specific test to evaluate the esophageal involvement (esophagogram, esophageal manometry, esophageal cintilography) and pulmonary involvement (simple radiography, pulmonary function tests, high resolution computed tomography, echocardiography) can be useful, being these organs frequently compromised in SSc.

It should also be investigated the use of drugs which can induce to RP (e.g. cyclosporine and nonselective beta blockers), exposure to toxic agents, specially chemotherapy and a history of repetitive traumas, mainly vibrational ones.

Finally, the presence of unilateral RP suggests an occupational lesion or disease (e.g. workers who use vibratory instruments or are exposed to high frequencies for long periods of time). The thoracic outlet syndrome manifests itself via neurological symptoms and vascular compression associated with unilateral RP in $45 \%$ of the cases. The investigation should be complemented with image tests (radiography of the cervical spine, angiography or magnetic resonance imaging). Whereas the hypothenar hammer syndrome is related with a dysplasia of the anterior ulnar artery, with formation of an aneurysm which later suffers a thrombosis, resulting in a constant "hammering" over the hands volar face, with the possibility of evolving with numbness, discoloration of the hands and even formation of an ulcer on the tip of the fingers. The diagnosis can be clinically confirmed by the Allen test, or by an ultrasound with Doppler or arteriography. ${ }^{3}$

\section{TREATMENT}

In individuals with primary RP pharmacological treatment is not generally necessary, general measures such as avoiding cold exposure and patient education are usually adequate. ${ }^{36}$ On the contrary the RP secondary to rheumatic autoimmune diseases will often need drug treatment. In theses cases, the severity and complications associated should be evaluated and the treatment should be stratified for each case. Other causes, if identified (e.g. thoracic outlet syndrome), should also be adequately treated. The objective of the treatment should be to decrease the severity and the number of RP episodes and to prevent new ischemic lesions. Some authors believe that even patients with SSc with less severe RP episodes should be treated to prevent repeated episodes of ischemia reperfusion, but there is not an agreement regarding this orientation. However, patients with a history or evidence of ischemic lesions, such as ulcers or microscars of the digital pulp, should be treated this way. ${ }^{37} \mathrm{We}$ will discuss in detail the treatment of RP associated with autoimmune rheumatic diseases, mainly to SSc, since most of the clinical trials were performed in this group of patients (Table 4).

\section{NONPHARMACOLOGICAL THERAPY}

Patients with mild RP may be managed just with cold protection measures. Higher temperatures are considered the best treatment to RP. In this context, all the patients should avoid exposure to cold and wear warm clothes, besides gloves, hood etc. It should also be avoided the use of agents that induce important vasoconstriction like sympaticomimetic drugs, clonidin, ergotamine, caffeine and beta blockers. Control of emotions and anxieties through therapies that reduce stress can have a benefic effect, since stress can unleash or aggravate the vasoconstriction. Smoking cessation is essential in patients with SSc. ${ }^{37,38}$

\section{Table 4}

Pharmacologic treatment of Raynaud's phenomenon

\begin{tabular}{|c|c|c|}
\hline & Dosage & Effectiveness \\
\hline \multicolumn{3}{|l|}{ CCB } \\
\hline Nifedipine & 10-30 mg 3-4x/day & ++ \\
\hline Anlodipine & 2.5-10 mg/day & ++ \\
\hline Diltiazen & $30-90 \mathrm{mg} 3-4 x /$ day & $+/-$ \\
\hline Captopril & $12.5-25 \mathrm{mg} 3 x /$ day & $+/-$ \\
\hline Losartan & $50 \mathrm{mg} /$ day & $+/-$ \\
\hline \multicolumn{3}{|c|}{ Sympatolitics } \\
\hline Prazosin & $1-5 \mathrm{mg} 2-3 x /$ day & ++ \\
\hline Pentoxifiline & 400 mg 3x/day & $+/-$ \\
\hline Fluoxetine & $20 \mathrm{mg} /$ day & $+/-$ \\
\hline \multicolumn{3}{|c|}{ Endovenous prostaglandins } \\
\hline Bosentan & 62.5-125 mg/day & ++ \\
\hline Sildenafil & $12.5-100 \mathrm{mg} /$ day & + \\
\hline
\end{tabular}

$\mathrm{CCB}=$ Calcium channel blockers 
Some alternative therapies like acupuncture, low frequency laser therapy and gloves impregnated with ceramic showed insufficiently expressive results.

\section{PHARMACOLOGICAL THERAPY}

Calcium channel blockers. The calcium channel blockers are vasodilating drugs, considered the first choice in the treatment of RP. Nifedipine is the most used drug, and it is considered effective for the treatment of RP primary and secondary to SSc. It should be given preference to the slow release formulations (SR). In two metanalysis performed by Thompson et al. the authors found a moderate reduction in the average number of attacks and an improvement of $33 \%$ and $35 \%$ in the severity of primary RP and associated to SSc, respectively. ${ }^{39,40}$ Recently, our group also evaluated the acute effect of nifedipine on the test of lacticemia of digital pulp before and after cold stimulus (LDP-CS) in a randomized, double-blind and placebo-controlled clinical trial with a cross-over design in 20 patients with primary RP and 20 with SSc. We observed a benefic effect of the sublingual nifedipine on the microcirculation, mainly in the group of patients with SSc. ${ }^{41}$ Adverse effects include hypotension, headache and lower extremity edema. It should also be remembered that the calcium channel blockers can worsen the reflux symptoms since they reduce the pressure of the lower esophagean sphincter. The third generation of dihydropiridines (amlodipine, felodipine) appears to be as effective as nifedipine; ${ }^{37}$ besides, they present a longer half-life than other dihydropiridines, enabling their administration in a single daily dose. Diltiazem and verapamil are less effective. ${ }^{3}$

\section{ACE inhibitors and angiotensin II receptor antagonists.} The ACE inhibitors changed dramatically the course of scleroderma renal crisis. However, studies that evaluated captopril or enalapril in the treatment of RP showed modest or inconclusive results, mainly in patients with $\mathrm{SSc} .{ }^{37} \mathrm{~A}$ recent randomized, multicentric, placebo-controlled trial with 210 patients with limited SSc or RP in the presence of specific autoantibodies, did not show benefits after two to three years of treatment with quinapril on the occurrence of digital ulcers and other peripheral vascular manifestations. ${ }^{42}$ Losartan $50 \mathrm{mg}$ /day was better than nifedipine $40 \mathrm{mg} /$ day in decreasing attack frequency and severity and also improved vascular parameters, most notably in patients who had primary RP, the results were marginal in patients with RP secondary to SSc. ${ }^{43}$ Our group also found modest results with losartan 50-100 mg/day in an open study, with 10 patients with SSc. ${ }^{44}$

Nitrates. Topic nitroglycerin seem to be effective and is an option for the treatment of patients with RP secondary to SSc.
Nevertheless, the nitroglycerin possesses a vasodilating action and even its topic use can cause side effects such as headache and cutaneous rash. ${ }^{45}$

Alpha-adrenergic blockers. Few studies evaluated the $\alpha$-adrenergic blockers in patients with RP. ${ }^{38}$ In a Cochrane review, two studies showed modest results with prazosin for the treatment of RP. Hypotension is a frequent side effect. ${ }^{46}$ In a more recent study, a selective blocker $\alpha 2 \mathrm{c}$-adrenergic receptor antagonist (OPC-28326), significantly improved digital perfusion in patients with RP secondary to $\mathrm{SSc}{ }^{47}$

Serotonin antagonists. The serotonin is a vasoconstricting mediator and, because of that, its antagonists could have a beneficial effect in patients with RP. ${ }^{48}$ Still, the ketanserin was not effective in the treatment of patients with RP secondary to SSc. ${ }^{38}$ While fluoxetine, a selective serotonin reuptake inhibitor, showed beneficial effects on the number and severity of RP attacks in a controlled study. ${ }^{49}$

Prostaciclin analogs. Prostaglandins are potent vasodilating agents used in the treatment of pulmonary hypertension, that also inhibit platelet aggregation, have an antiproliferative effect in smooth muscular cells, and other biological properties, which can increase the vascular permeability. ${ }^{38}$ Although still rare in our country, the prostanoids under endovenous form (iloprost, alprostadil, epoprostenol) are extensively used in Europe and in the United States for the treatment of severe RP, with ischemia or digital ulcers. ${ }^{38,48}$ Intravenous administration of iloprost has been repeatedLy shown to improve severe Raynaud's attacks and ischemic ulcerations. ${ }^{50,51}$ However the prostaciclin analogs with oral preparation are not effective. ${ }^{52}$

Endothelin receptors antagonists. Endothelin is a powerful vasoconstricting agent, strongly implicated in the SSc pathogenesis. Bosentan is an oral endothelin receptor antagonists, effective in the treatment of pulmonary hypertension. Two multicentric, double-blind and placeo-controlled trials, (RAPIDS-1 and RAPIDS-2) were performed with a large number of patients to evaluate the effectiveness of bosentan in the treatment and prevention of the ischemic acute ulcers in patients with SSc. ${ }^{53,54}$ The RAPIDS-1 study showed that bosentan was effective in the prevention of new digital ulcers (an average of $48 \%$ less than placebo). Hand function improved, but there was no effect on healing of preexisting ulcers (secondary endpoint). RAPIDS-2 was a study involving a larger number of patients that confirmed the findings of RAPIDS- 1 in relation to the prevention of new ulcers. The use of this substance should be considered in patients with an important vasculopathy, with recurrent refractory ulcers. ${ }^{38}$ Recently, our group used Bosen$\tan$ in three patients with SSc and with refractory extremities 
ulcers. We obtained cicatrization or diminution of the diameter of all the ulcers after 8 weeks of treatment.

Phosphodiesterase inhibitors. Sildenafil is a vasodilating agent used also in the treatment of pulmonary hypertension. Studies with a small group of patients showed an improvement of RP and ischemic ulcers. ${ }^{38}$ In a double-blind, placebocontrolled study with sildenafil $100 \mathrm{mg} /$ day in patients with secondary RP, the authors observed an improvement of the symptoms and of the blood flow after 4 weeks of treatment. ${ }^{55}$ Cilostazol, an inhibitor of phosphodiesterase type 3, didn't show improvement in the symptoms or in the blood flow of the microcirculation after six weeks of treatment. ${ }^{56}$ Studies with a larger number of patients are necessary to confirm the real effectiveness of this group of drugs.

Antiaggregating and others. Although there is no evidence of its benefits, the use of low doses of aspirin ( $100 \mathrm{mg} /$ day $)$ is recommended to patients with SSc, mainly those with recurrent ulcers or episodes of important digital ischemia. As the oxidative stress plays an important roll in the pathogenesis of the SSc, the use of antioxidant agents has been the object of some studies, although there is controversy, they seem useful mainly in early phases of the disease, before the establishment of irreversible vascular lesions, in association with other therapeutic modalities. Finally, it should be mentioned the pentoxifilin, an agent with the capacity of improving the rheologic characteristic of blood (increases the flexibility of the erythrocytes and decreases the blood viscosity). It can be used in combination with other vasodilating agents. However, it needs controlled clinical trials to demonstrate its real effectiveness. ${ }^{37,38}$

\section{ISCHEMIC ULCERS TREATMENT}

A frequent complication in RP secondary to SSc are the extremities ulcers, which generally are intensely painful and disabling, and can evolve with a secondary infection, gangrene and even amputation. Besides the pharmacological therapy with vasodilating agents, the basic principle for the treatment of extremities ulcers in patients with RP begins with the debridement and adequate cleaning of the lesions, followed by the use of occlusive curatives and antibioticotherapy when necessary. Occlusive curatives can be useful to protect the susceptible areas from traumas as well as to the cicatrization of ulcers. ${ }^{57}$ Topic curatives of hydrocolloid showed to be safe and effective in promoting the cicatrization of digital ulcers in a controlled and randomized trial. ${ }^{58}$ Patients with sustained ischemia can require hospitalization for a more aggressive treatment. Anticoagulation with heparin for 24-72 hours can be considered for cases of acute ischemic events with fast evolution. ${ }^{37}$

\section{SURGICAL TREATMENT}

Simpathectomy should be reserved to patients, with severe $\mathrm{RP}$ and associated complications, who did not respond to drug treatment. The effect is usually temporary, mainly in patients with RP secondary to SSc. Digital sympathectomy or chemical sympathectomy with lidocaine or bupivacain can be used in patients with critical ischemia and active ulcers, did not respond to pharmaceutical treatment. Cervical sympathectomy is related to postsurgical complications such as hypothenar hammer syndrome and neuralgy and is rarely recommended. ${ }^{38}$

\section{CONCLUSIONS}

Raynaud's phenomenon is relatively frequent in general population, being important the differentiation between primary and secondary RP. The treatment of RP has advanced with the advent of novel drugs with potent vasodilating action. However, protection from cold and the use of calcium channels blockers are still the first choice treatment. Therapeutic associations and novel vasodilating drugs should be used in patients who did not respond to the initial measures and to the calcium channel blocking drugs. New alternatives, like the endothelin 1 receptors antagonists, the phosphodiesterase $\mathrm{V}$ inhibitors and the prostacyclin analogs seem to have a place in the management of the ischemic ulcers of difficult treatment, mainly in patients with SSc.

\section{REFERÊNCIAS BIBLIOGRÁFICAS}

\section{REFERENCES}

1. Wigley FM. Raynaud's phenomenon. N Engl J Med 2002;347:1001-8.

2. LeRoy EC, Medsger TA Jr. Raynaud's phenomenon: a proposal for classification. Clin Exp Rheumatol 1992;10:485-8.

3. Gayraud M. Raynaud's phenomenon. Joint Bone Spine 2007; 74:e1-e8.

4. Maricq HR, Weinrich MC, Keil JE, LeRoy EC. Prevalence of Raynaud's phenomenon in the general population. A preliminary study by questionnaire. J Chronic Dis 1986;39:423-7.

5. Weinrich MC, Maricq HR, Keil JE, McGregor AR, Diat F. Prevalence of Raynaud phenomenon in the adult population of South Carolina. J Clin Epidemiol 1990;43:1343-9.

6. Maricq HR, Carpentier PH, Weinrich MC, Keil JE, Franco A, Drouet $\mathrm{P}$, et al. Geographic variation in the prevalence of Raynaud's phenomenon: Charleston, SC, USA, vs Tarentaise, Savoie, France. J Rheumatol 1993;20:70-6. 
7. Suter LG, Murabito JM, Felson DT, Fraenkel L. The incindence and natural history of Raynaud's phenomenon in the community. Arthritis Rheum 2005;52:1259-63.

8. Jones, GT, Herrick, AL, Woodham, SE, Baildam EM, MacFarlane GJ, Silman AJ. Ocurrence of Raynaud's phenomenon in children aged 12-15 years. Arthritis Rheum 2003;48:3518-23.

9. Planchon B, Pistorius MA, Beurrier P, Deaucal P. Primary Raynaud's Phenomenon: age of onset and pathogenesis in a prospective study of 424 patients. Angiology 1994;45:677-86.

10. Herrick AL. Pathogenesis of Raynaud's phenomenon. Rheumatology 2005;44:587-96.

11. Flavahan NA. Regulation of Vascular Reactivity in Scleroderma: New Insights into Raynauds Phenomenon. Rheum Dis Clin N Am 2008;34:81-7.

12. Flavahan NA, Flavahan S, Mitra S, Chotani MA. The vasculopathy of Raynaud's phenomenon and scleroderma. Rheum Dis Clin North Am 2003;29:275-91.

13. Schachna L, Wigley FM. Targeting mediators of vascular injury in scleroderma. Curr Opin Rheumatol 2002;14:686-93.

14. Clapp LH, Finney P, Turcato S, Tran S, Rubin LJ, Tinker A. Differential effects of stable prostacyclin analogs on smooth muscle proliferation and cyclic AMP generation in human pulmonary artery. Am J Respir Cell Mol Biol 2002;26:194-201.

15. Campbell PM, LeRoy EC. Pathogenesis of systemic sclerosis: a vascular hypothesis. Semin Arthritis Rheum 1975;4:351-68.

16. Suderkötter C, Riemekasten G. Pathophysiology and clinical consequences of Raynaud's phenomenon related to systemic sclerosis. Rheumatology 2006;45(S3):iii33-5.

17. Fuzii HT, Yoshikawa GT, Junta CM, Sandrin-Garcia P, Fachin AL, Sakamoto-Hojo ET, et al. Affected and non-affected skin fibroblasts from systemic sclerosis patients share a gene expression profile deviated from the one observed in healthy individuals. Clin Exp Rheumatol 2008;26(5):866-74.

18. Herrick AL, Matucci Cerinic M. The emerging problem of oxidative stress and the role of antioxidants in systemic sclerosis. Clin Exp Rheumatol 2001;19:4-8.

19. Silveri F, De Angelis R, Poggi A, Muti S, Bonapace G, Argentati F, et al. Relative roles of endothelial cell damage and platelet activation in primary Raynaud's phenomenon (RP) and RP secondary to systemic sclerosis. Scand J Rheumatol 2001;30:290-6.

20. Herrick AL, Illingworth K, Blann A, Hay CRM, Hollis S, Jayson MIV. Von Willebrand factor, thrombomodulin, thromboxane, beta-thromboglobulin and markers of fibrinolysis in primary Raynaud's phenomenon and systemic sclerosis. Ann Rheum Dis 1996;55:122-7.

21. Lau CS, Bridges AB, Muir A, Scott N, Bancroft A, Belch JJF. Further evidence of increased polymorphonuclear cell activity in patients with Raynaud's phenomenon. Br J Rheumatol 1992;31:375-80.

22. Freedman RR, Mayes MD. Familial aggregation of primary Raynaud's disease. Arthritis Rheum 1996; 39:1189-91.

23. Block JA, Sequeira W. Raynaud's phenomenon. Lancet 2001;357:2042-8.

24. Belch J. Raynaud's phenomenon. Cardiovasc Res 1997;33:25-30.

25. Spencer-Green G. Outcomes in primary Raynaud phenomenon. A meta-analysis of the frequency, rates, and predictors of transition to secondary diseases. Arch Intern Med 1998;158:595-600.
26. Ziegler S, Brunner M, Eigenbauer E, Minar E. Long-term outcome of primary's Raynaud's phenomenon and its conversion to connective tissue disease: a 12-year retrospective patient analysis. Scand J Rheumatol 2003;32:343-7.

27. Luggen M, Belhorn L, Evans T, Fitzgerald O, Spencer-Green G. The evolution of Raynaud's phenomenon: a longterm prospective study. J Rheumatol 1995;22:2226-32.

28. Weiner ES, Hildebrandt S, Senécal JL, Daniels L, Noell S, Joyal $\mathrm{F}$, et al. Prognostic significance of anticentromere antibodies and anti-topoisomerase I antibodies in Raynaud's disease. A prospective study. Arthritis Rheum 1991;34:68-77.

29. Priollet P, Vayssairat M, Housset E. How to classify Raynaud's phenomenon. Long-term follow-up study of 73 cases. Am J Med 1987;83:494-8.

30. Maricq HR, Harper FE, Khan MM, Tan EM, LeRoy EC. Microvascular abnormalities as possible predictors of disease subsets in Raynaud phenomenon and early connective tissue disease. Clin Exp Rheumatol 1982;1:195-205.

31. Wollersheim H, Thien T, Hoet MH, Van Venrooy WJ. The diagnostic value of several immunological tests for anti-nuclear antibody in predicting the development of connective tissue disease in patients presenting with Raynaud's phenomenon. Eur J Clin Invest 1989;19:535-41.

32. Cutolo M, Grassi W, Matucci-Cerinic M. Raynaud's phenomenon and the role of capillaroscopy. Arthritis Rheum 2003;48:3023-30.

33. Andrade LEC, Gabriel JrA, Assad RL, Ferrari AJL, Atra E. Panoramic Nailfold capillaroscopy: a new reading method and normal range. Seminars Arthritis Rheum 1990; 20:21-31.

34. Maricq HR. Wide-field capillary microscopy. Arthritis Rheum 1981;24:1159-65.

35. Furtado RN, Pucinelli ML, Cristo VV, Andrade LE, Sato EI. Scleroderma-like nailfold capillaroscopic abnormalities are associated with anti-U1-RNP antibodies and Raynaud's phenomenon in SLE patients. Lupus 2002;11:35-41.

36. Vinjar B, Stewart M. Oral vasodilators for primary Raynaud's phenomenon. Cochrane Database Syst Rev 2008; 2:CD006687.

37. Hummers LK, Wigley FM. Management of Raynaud's phenomenon and digital ischemic lesions in scleroderma. Rheum Dis Clin North Am 2003;29:293-313.

38. Herrick A. Diagnosis and management of scleroderma peripheral vascular disease. Rheum Dis Clin North Am 2008; 34:89-114.

39. Thompson AE, Pope JE. Calcium channel blockers for primary Raynaud's phenomenon: a meta-analysis. Rheumatology 2005;44:145-50.

40. Thompson AE, Shea B, Welch V, Fenlon D, Pope JE. Calciumchannel blockers for Raynaud's phenomenon in systemic sclerosis. Arthritis Rheum 2001;44:1841-7.

41. Fontenelle SM, Kayser C, Pucinelli ML, Andrade LE. Cold stimulus fingertip lacticemy test: an effective method to monitor acute therapeutic intervention on primary Raynaud's phenomenon and systemic sclerosis. Rheumatology 2008;47:80-3.

42. Gliddon AE, Doré CJ, Black CM, McHugh N, Moots R, Denton CP, et al. Prevention of vascular damage in scleroderma and autoimmune Raynaud's phenomenon: a multicenter, randomized, double-blind, placebo-controlled trial of the angiotensin-converting enzyme inhibitor quinapril. Arthritis Rheum 2007;56:3837-46. 
43. Dziadzio M, Denton CP, Smith R, Howell K, Blann A, Bowers E, et al. Losartan therapy for Raynaud's phenomenon and scleroderma: clinical and biochemical findings in a fifteen-week, randomized, parallel-group, controlled trial. Arthritis Rheum 1999; 42:2646-55.

44. Kayser C, Santos MF, Andrade LEC. Estudo piloto sobre a eficácia do losartan no tratamento do fenômeno de Raynaud (FRy) e correlação com alterações na microcirculação em pacientes com esclerose sistêmica (ES). Rev Bras Reumatol 2005;45:343-50.

45. García-Carrasco M, Jiménez-Hernández M, Escárcega RO, Mendoza-Pinto C, Pardo-Santos R, Levy R, et al. Treatment of Raynaud's phenomenon. Autoimmun Rev 2008;8:62-8.

46. Pope J, Fenlon D, Thompson A, Shea B, Furst D, Wells G, et al. Prazosin for Raynaud's phenomenon in progressive systemic sclerosis. Cochrane Database of Syst Rev 2000;2:CD000956.

47. Wise RA, Wigley FM, White B, Leatherman G, Zhong J, Krasa H, et al. Efficacy and tolerability of a selective alpha(2C)-adrenergic receptor blocker in recovery from cold-induced vasospasm in scleroderma patients: a single-center, double-blind, placebo-controlled, randomized crossover study. Arthritis Rheum 2004;50:3994-4001.

48. Riemekasten G, Sunderkötter C. Vasoactive therapies in systemic sclerosis. Rheumatology 2006;45(S3):iii49-51.

49. Coleiro B, Marshall SE, Denton CP, Howell K, Blann A, Welsh KI, et al. Treatment of Raynaud's phenomenon with the selective serotonin reuptake inhibitor fluoxetine. Rheumatology 2001;40:1038-43.

50. Pope J, Fenlon D, Thompson A, Shea B, Furst D, Wells G, et al. Iloprost and cisaprost for Raynaud's phenomenon in progressive systemic sclerosis. Cochrane Database of Syst Rev 2000;2:CD000953.
51. Rademaker M, Cooke ED, Almond NE, Beacham JA, Smith RE, Mant TG, et al. Comparison of intravenous infusions of iloprost and oral nifedipine in treatment of Raynaud's phenomenon in patients with systemic sclerosis: a double blind randomised study. BMJ 1989;298:561-4.

52. Wigley FM, Korn JH, Csuka ME, Medsger TA Jr, Rothfield NF, Ellman M, et al. Oral iloprost treatment in patients with Raynaud's phenomenon secondary to systemic sclerosis: a multicenter, placebocontrolled, double-blind study. Arthritis Rheum 1998;41:670-7.

53. Korn JH, Mayes M, Matucci Cerinic M, Rainisio M, Pope J, Hachulla $\mathrm{E}$, et al. Digital ulcers in systemic sclerosis: prevention by treatment with bosentan, an oral endothelin receptor antagonist. Arthritis Rheum 2004;50:3985-93.

54. Seilbold JR, Matucci-Cerinic M, Denton CP, et al. Bosentan reduces the number of new digital ulcers in patients with systemic sclerosis [abstract]. Ann Rheum Dis 2006;65(S2):90.

55. Fries R, Shariat K, von Wilmowsky H, Böhm M. Sildenafil in the treatment of Raynaud's phenomenon resistant to vasodilatory therapy. Circulation 2005;112:2980-5.

56. Rajagopalan S, Pfenninger D, Somers E, Kehrer C, Chakrabarti A, Mukherjee D, et al. Effects of cilostazol in patients with Raynaud's syndrome. Am J Cardiol 2003;92:1310-5.

57. Chung L, Fiorentino D. Digital ulcers in patients with systemic sclerosis. Autoimmun Rev 2006;5:125-8.

58. Milburn PB, Singer JZ, Milburn MA. Treatment of scleroderma skin ulcers with a hydrocolloid membrane. J Am Acad Dermatol 1989;21:200-4. 